\begin{tabular}{|c|c|c|c|c|c|c|c|c|c|c|c|}
\hline \multirow{2}{*}{$\begin{array}{l}\text { 货驗 } \\
\text { 番號 }\end{array}$} & \multirow{2}{*}{ 試 } & \multirow[b]{2}{*}{ 藥 } & \multicolumn{2}{|c|}{ 處理條件 } & \multirow{2}{*}{$\begin{array}{l}\text { 時 } \\
\text { 間 }\end{array}$} & \multicolumn{3}{|c|}{ 回收セテン性質 } & \multirow{2}{*}{$\begin{array}{c}\text { 同セテン } \\
\text { 收 }_{\%}^{\text {量 }}\end{array}$} & \multirow{2}{*}{$\begin{array}{c}\text { 酸 㵋 } \\
\text { (精製酸) }\end{array}$} & \multirow[b]{2}{*}{ 请 } \\
\hline & & & 溫度 ${ }^{\circ} \mathrm{C}$ & 䇪 & & $\begin{array}{l}\text { 沃素蜺 } \\
(\mathrm{Wijs})\end{array}$ & $\begin{array}{l}\text { 比重 } \\
d_{4}^{20}\end{array}$ & $\begin{array}{c}\text { 届折率 } \\
n_{\mathrm{D}}^{20}\end{array}$ & & & \\
\hline 1 & - & & 290 & 1 氣厭 & 5 & 107 & 0.7800 & 1. 4425 & 28.3 & 230.5 & 热重合蓄し \\
\hline 2 & 金閩 $\mathrm{Na}$ & & 150 & $15 \mathrm{mmHg}$ & 5 & 107 & 0.7800 & 1. 4418 & 78.3 & 231.0 & 一部分解する \\
\hline 3 & $N / 2$. 酶精性刀 & リ(5 倍容量) & 沸騰 & 1 氮腿 & 20 & 108 & 0.7794 & 1.4110 & 90.0 & \multicolumn{2}{|c|}{230.0} \\
\hline 4 & $\mathrm{ZnCl}_{2}(5 \%)^{*}$ & & $270 \sim 280$ & 同上 & $' 5$ & 107 & 0.7792 & 1.4403 & 61.5 & \multicolumn{2}{|c|}{ 230.5分解重合共に起る } \\
\hline 5 (a) & $\mathrm{ZnCl}_{2}(2,7 \%)$ & 水 $(2.0 \%)$ & $270 \sim 300$ & 封管中 & 2 & $1 \subset 4$ & 0.7790 & 1.4400 & 81.6 & 240.8 & *臸をテン重量 \\
\hline $6(\mathrm{~b})$ & $\mathrm{ZnCl}_{2}(10 \%)$ & 水 $(7.35 \%)$ & 300 & 250氣㭢(水素) & 3 & 73.6 & 0.7769 & 1. 4353 & 73.7 & 320.0 & 分解重合共に起 \\
\hline 7 & $\mathrm{ZnCl}_{2}(10 \%)$ & & $\subsetneq 00 \sim 310$ & $185 " \prime(")$ & 2.5 & 84.0 & 0.7765 & 1.4398 & 72.5 & 295.0 & y，水添著し \\
\hline 8 & $\mathrm{Zn}$ 粉末 $(10 \%)$ & & $290 \sim 300$ & $80 " 1 /(1)$ & 2.5 & 85.7 & 0.7786 & 1.4390 & 76.5 & 280.0 & 同上 \\
\hline 9 & - & & $300 \sim 310$ & $80 " 1 /()$ & 2.5 & 87.0 & 0.7790 & 1. 4395 & 78. 0 & 250.0 & 同 上 \\
\hline
\end{tabular}

合の移動を起したことになる。

(a) $\mathrm{ZnCl}_{2}$ の觸媒作用は水の存在寸る場合. $\mathrm{H}_{2}\left[(\mathrm{OH})_{2} \mathrm{ZnCl}_{2}\right]$ として作用すると考へられ，その觸媒作用の最大なときの $\mathrm{ZnCl}_{2}$ 濃度は 11.2 モ溶液である (Meerwein, Ann. , 1927, 455, 227)。

(b) バルミチン酸の水素高壓水添脫水反應に際して生成する 水の量は，バルミチン酸に對して $12.1 \%$ でする。反應は耐酸鋼

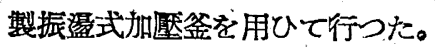

實驗番號 (7) で得られた脂肪酸 (酸價 295) 4g を常法に依り 分離 (た所, $\mathrm{C}_{10}$ 以上酸收量 $3.65 \mathrm{~g}$ (酸賈 246.7)， $\mathrm{C}_{8}$ 酸收量 0.6 g (酸價 352) なる結果を得た。

\section{總括}

以上の結果を檢討して次のことを結論し得る。(1) 丸田法に依 り得られるセテンは, 少くもセテン-1, セテン-4，セテン-8 等二 重結合の位置を異にする異性體の混合物意むる。(2) 普通實驗室

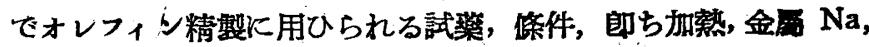
$\mathrm{KOH}$ に依る處理では, セテン-1 二重結 合の移動は起らない。

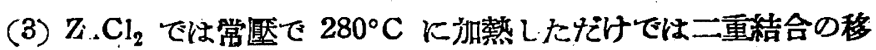
動は起らないが, 封管中少量の水の存在で $300^{\circ} \mathrm{C}$ に妿熱すれば, 少 $\mathrm{L}$ く重結合の移動を起すに至る。(4) 脂肪酸の高壓水添脱水 反應に依るオンフィン製造條件に於ては (i) $\mathrm{ZnCl}_{2}$ 支び水，(ii) $\mathrm{ZnCl}_{2}$, (iii) $\mathrm{Zn}$ 粉末; (iv) '水素壓單㺈, 何れの場合もセテン-1 二重紿合の移動を起し，その强さは (i)，(ii)，(iii)，(iv) の順 序である。 $\mathrm{ZnCl}_{2}$ K依る二重結合の移動は著しいののであるが の場合二重結合の移動は，七テン分子の中央汽䔟動与る分子す ある。即ちセテン-8 る生成する。

本研究に對 【御指導, 御鞭挂を睗つた北大理學部杉野目晴貞数 授，種々御高配を睗つた馬語哲郎博士に厚く感謝の意を表する。 又セテン-1の合成は佐々木榮一理學士に依れるるのでする。附記 して謝意を表す。(北大理學部化學㸚室：昭和 22.5.17 受理)

\title{
（74）親油性部を有するスルフォン酸の應用に關する砫究（第1 報）
}

\section{コンタクト及びチブルソン D の浮選劑としての試用に就て}

\section{福珄 \\ 緒 \\ 百}

數系列のスルフォン酸が起泡劑或は起泡捕收凨として出現した 中で，アルミニウム鑛に對する浮選劑としては Espumin がある (A. Lottermoser, Kolloid-Beih., 1932,35,372)。著者は從來油 脂分解劑として使用されたるコンタクト及びヂブルゾン D の如 き親油性部を有するスルフォン酸を礬土頁岩に對する浮選劑とし て試用した。先づそれ等の珠石及びボーキサィトに對する浮鈸作 用を检討 し, 次で䄷土頁岩に對する浮選試驗を行ひ, 浮選劑と l てオレイン酸, 樟腦白油等を用ひた場合と比較した。

\section{霬驗方法}

跔料 コンタクト及びヂブルゾンDは市販品を用ひ，オレイン 酸, 樟腦白油, 水ガラス $\left(\mathrm{Na}_{2} \mathrm{O} 18.01 \%, \mathrm{SiO}_{2} 36.41 \%\right)$, 無水 炭酸ソーダ及び硫酸は化學用純品を伐用した。迋石は備前迹 $\left(\mathrm{SiO}_{2} 95.99 \%\right) ，$ ボーキサイトはリオ群島ビンタン島这 $\left(\mathrm{SiO}_{2}\right.$ $3.37 \%)$ ，禁上頁岩は中國河北省古冶迹のものを使用し，何れる

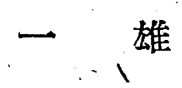

鈸粒細度を一200 メッシュにした。銓液用水は蒸溜水を用ひた。

裝置 浮潠機は Denver Equipment Mach!ne を若にして 木製の $50 \mathrm{~g}$ 用浮選試驗機を作製した。. 木の䋹目にはべークライ トA を塗り込みこれを加熱して接着せしめ，試驗嘰の内面には ラッカーを塗裝した。 $\mathrm{pH}$ 價測定器は島津製作所製迅速水素イオ ン計を用ひた。

懆作 試藥はすへて注射針にて两へた。浮選實驗は小型浮選試 驗機を使用して普通行はれてるる操作を踏䡛した。

\section{實 驗 結 果}

コンタクト及びヂブルン゙ン D 及びオレイン酸, 樟腦白油等の 珪石及びボーキサイトに對する浮銀作用を第1表に示した。

珪石の浮銓量は，コンタクトを用ひた場合，水がラス，無水炭 酸ソーダ或は硫酸の併用により增大する。ヂブルゾン D はコン タクトよりも浮銈作用大なる故鎘液濃度を $10 \%$ とした。浮選時 間 10 分の場合には，コンタクトすデブルゾン D も夫ネ單第に

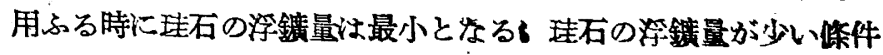




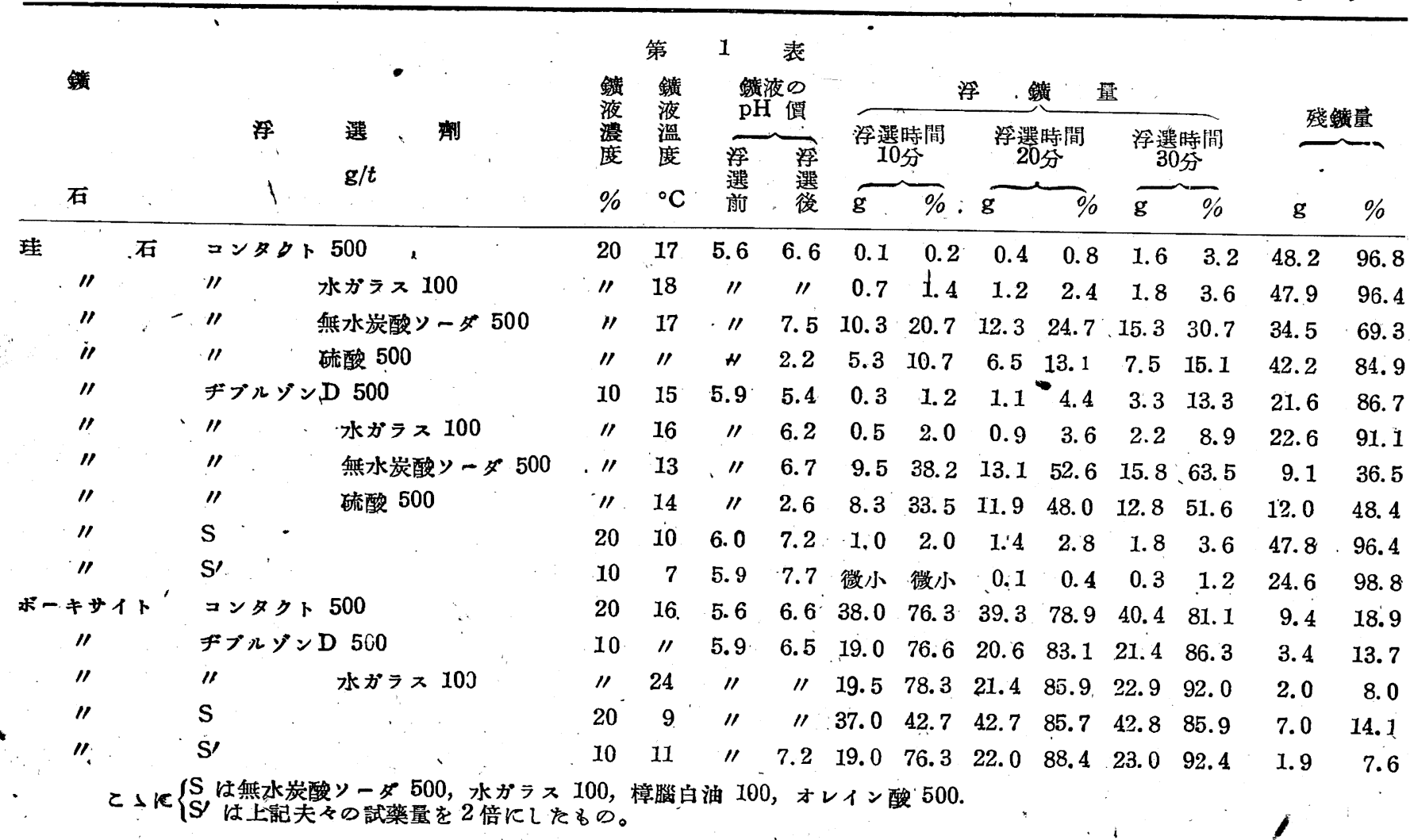

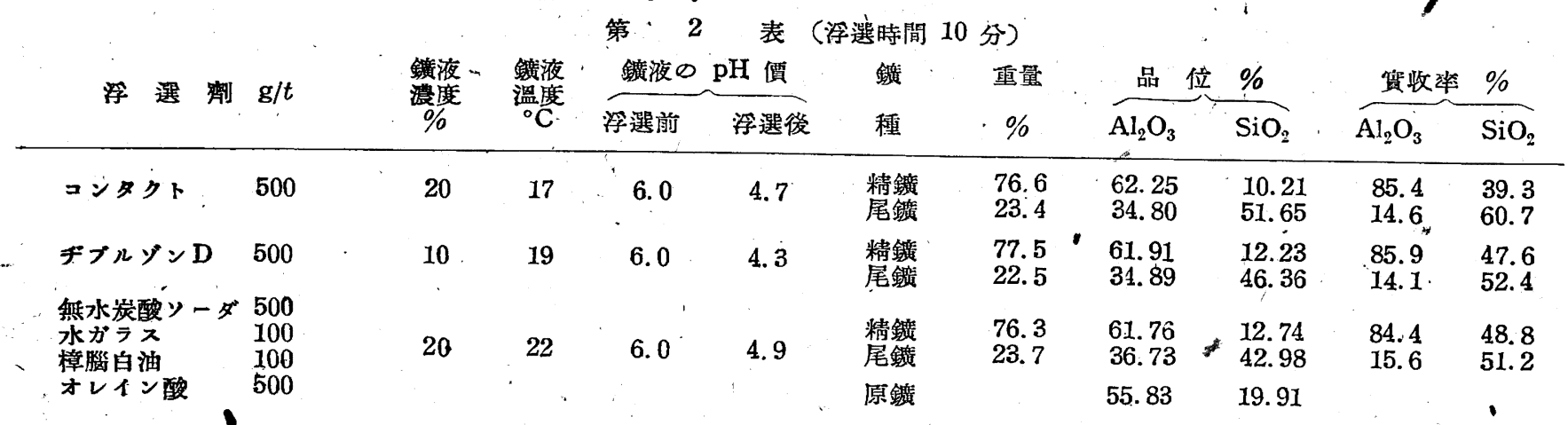

の下でも，ホホーキサイトトの浮鑛量は相當である。䥄液濃度 $20 \%$ ， ロンタク゚ト $500 \mathrm{~g} / t$ 使用の場合及び鑛液濃度 $10 \%$ ，ヂブルゾン D $500 \mathrm{~g} / t$ 使用の場合は，鐄液濃度 $20 \%$ ，オレイン酸, 樟腦白油 等使用の埸合よりも，烓石の浮鑛量は少しく小で，ボーキサイト

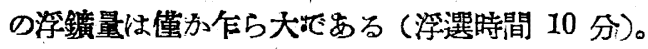

以上の結果を多少參にして，コンタクト及びデブルデンD 及 びオンイン酸, 樟腦白油等を用ひ攀土頁岩に對する浮選試驗を行 つた結果を第2 表記記した。

\section{總 . 括}

從來油脂分解劑として用ひられだコンタクト及びデブルゾンD
の如き親油性部を有するスルフォン酸の珪石及びボーキサイトに 對する浮鑛作用を調へた。次でそれ等を攀土頁岩に對する浮選劑 “として試用てた結果は，オレイン酸，樟腦白油等を用ひた結果よ り僅か乍ら良好であつた。コンタクト或はデブルゾンDによる攀 土頁岩の浮潠條件は次の如くとればよい。即ち鋠粒細度一200 メ ッシュ, 調整劑を加へず, 室溫にて行ひ， pH 價 4〜5, 浮選時

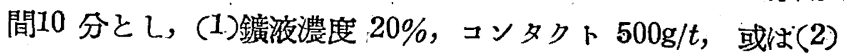
鑛液濃度 $10 \%$ ，デブルデン D $500 \mathrm{~g} / t$ にする。

終りに臨み種々御指導を賜つた名占屋帝國大學外山埥授並に內 海支所長に厚く慰謝の意を表す。(東工試名古屋支所：昭和 21 年 5 月第 49 年會講演：昭和 22.4 .7 受理) 